\title{
Editorial
}

\section{Editorial and CALL for papers: Human survival in a new era}

Journal of Public Health Policy (2017) 38, I63-166.

doi:IO.I057/s4I 27I-OI7-0072-I; published online, I3 March 2017

We have never shied away from controversies where the health of populations and their very survival may be at stake (see Box I below.) We have a sense that at this moment in history, more is at stake than at any time in our lives. The Bulletin of Atomic Scientists has just reset its 'Doomsday Clock' closer to midnight. The Clock was created in 1953 to indicate how close the world is to a nuclear holocaust and to encourage nuclear disarmament. The Clock seems to be moving toward midnight. At $23 \mathrm{~h}$ 57:30, we are nearer to nuclear annihilation than at any time since 1953, when scientists first presented the Clock to the world.

Although no other threat is as immediate as nuclear weapons, population health and survival are at risk from many causes. Many countries and their policies disfavor or threaten people in poverty, females, and others exploited for a long list of reasons, including race, ethnicity, sexual orientation, and religion. People become migrants and refugees fleeing war or economic instability, as well as environmental degradation. Bioterrorism enabled by gene editing and climate change may be long-term threats as great as nuclear weapons. Uncontrolled population growth exacerbates tensions. Health consequences can be disastrous - especially if they are coupled with aggression and violence carried out with modern weaponry.

No regime or form of government seems to be intrinsically protective. Democracies in Europe now have mainstream racist parties or rightwing 'populists' whose members hate immigrants - Muslims, Jews, and dark-skinned people - to name a few. Autocratic and corrupt states almost always target or fail to protect particular segments of their populations. In the United States, immigrants from Latin America have suffered from discrimination and the new President has made discrimination against those wanting to cross into the United States from 


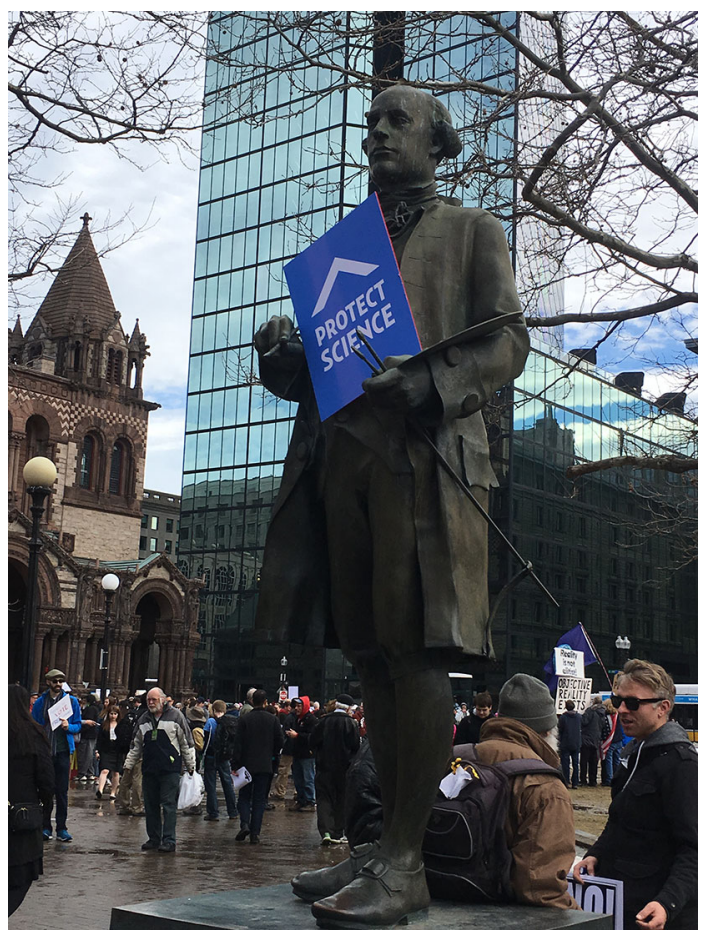

Stand Up for Science protest - Boston I9 February 20I7. Source: Author's own

Mexico, and against Muslims, his policy. In South Asia, and in Asia more generally, every country seems to disfavor one or more populations. Just one recent example is the mistreatment of the Rohingya in Myanmar - and denial of the same by the government. Poor health, death, and emigration usually follow. Early evidence may be found in deep in health statistics and in public records.

It is hard to overstate the importance of governments for improving public health. Resistant governments often respond to their peoples' demands based on facts. This explains why the facts themselves come under attack.

We in public health can bear witness, using all the tools in our hands. A first task for us all is vigilance to protect information sources. When information has posed threats to government policy — data have been blocked, data systems dismantled, or other measures taken to keep informative statistics from view. With information, health workers and 
researchers can undertake surveillance, analyze trends, and describe how determinants of health are altered. How and where are health and survival under threat? We can make otherwise invisible harm come to light by publicizing the health effects that may emerge in this changing world.

The first challenge is knowing where to investigate. Thus, we look to you to uncover impending harm to populations wherever you may see signs of trouble. We in health may be the first to know whether the threat is real or just worrisome. And we must try to mitigate harm and improve the health of populations.

THE CALL:

We invite colleagues around the world to submit to JPHP original research, analyses, and descriptions of threats to population health. What information and actions may help protect health? We call for research communities to conceptualize in future work ways to reveal changes in and threats to health. Can you suggest ideas that might develop into ways to understand a new generation of potential threats

Box I: Selected examples from JPHP: Original articles, Viewpoints, and Editorials

- Brenner, M.H. (2016) World Military Expenditures and global cardiovascular mortality. J Public Health Pol, 37: 20-35. doi:I0.I057/jphp.201 5.43

- Gilligan, J., Lee, B.X., Garg, S. et al. (2016) A case for studying country regimes in the public health model of violence. J Public Health Pol, 37(Suppl I): I33. doi:I0.I057/s4 I 27 I-0 I 6-0027-y

- Robbins, A. (20I6) How to understand the results of the climate change summit: Conference of Parties2 I (COP2I) Paris 20I 5, J Public Health Pol, 37: I29-I32. doi:I0.I057/jphp.20I 5.4

- 't Hoen, E and Pascual, F. (2015) Counterfeit medicines and substandard medicines: Different problems requiring different solutions. J Public Health Pol. 36: 384-389. doi:I0.I057/jphp.20I 5.

2

- Krimsky, S. (2013) Corporate philanthropy and conflicts of interest in public health. J Public

Health Pol, 34: I37-I39. doi:I0.1057/jphp.2012.6

- Roberts, B., Patel, P., Dahab, M. et al. (2013) The Arab Spring: Confronting the challenge of non-communicable disease J Public Health Pol, 34: 345-352. doi:I0.I057/jphp.20I3.I

- Robbins, A. \& Freeman, P. (20I5) Is WHO ineffectual because its members are ministries not states? J Public Health Pol, 36: I3 I-I33. doi:I0.1057/jphp.20 5.

- Siddiqi, A., Ornelas, I., Quinn, K. et al. (2013) Societal context and the production of immigrant status-based health inequalities: A comparative study of the United States and Canada, J Public Health Pol, 34: 330-344. doi:I0.1057/jphp.20I3.

- Robbins, A. and Freeman, P. (2013) Least Untruthful, a new standard? J Public Health Pol 34: 487-488. doi:IO.I057/jphp.20I3.3

- Robbins, A. (20I2) The CIA's vaccination ruse, J Public Health Pol (2012) 33: 387-389. doi:ıo. I057/jphp.2012.3

- Valenti, M., Freeman, P. \& Robbins, A. (2007) Special Section: Small Arms and Light Weapons in Africa-A Major Challenge to Public Health and Development. J Public Health Pol, 28: 387-388. doi:I0.IO57/palgrave.jphp.3200I 5 I 
to health? If so, we will give these submissions priority for publication.

\author{
Phyllis Freeman and Anthony Robbins \\ Co-Editors, \\ E-mails: Phyllis.Freeman@umb.edu; \\ Anthony.Robbins@tufts.edu
}

